\title{
Changes in cholesterol and free fatty acid content of Kars Gravyer Cheese (A Turkish dairy product produced by the traditional method)
}

\author{
Asya Çetinkaya', Fatih Öz ${ }^{2}$ \\ 1 - Kafkas University, Kars, Turkey \\ 2 - Ataturk University, Erzurum, Turkey
}

Keywords:

Gravyer

Cheese

Ripening

Fatty acid

Cholesterol

\section{Article history:}

Received

19.08.2018

Received in

revised form

12.09.2018

Accepted

28.09.2018

Corresponding author:

Asya Çetinkaya

E-mail:

a_cetinkaya36@

hotmail.com

DOI:

$10.24263 / 2304-$

974X-2018-7-3-6

\section{Abstract}

Introduction. This study was carried out to determine changing in the ratio of free fatty acids and cholesterol depended on the maturation period of Kars Graiver cheese produced in the traditional way, and the affect of the duration of maturation on the fatty acids composition and cholesterol levels.

Materials and methods. The fat content of the cheese samples was determined by Gerber's method. Flame Ionization DetectorGas Chromatography (GC/FID) was used to determine the fatty acids composition and cholesterol content.

Results and discussion. It was found the fat content of Kars Gravyer Cheese samples was between 27.0-38.50\%. The cholesterol content in the cheese samples ranged from 45.70 to $55.80 \mathrm{mg} / 100 \mathrm{~g}$ during 90 days of maturation. In Kars Gravyer Cheese samples, 16 saturated and unsaturated fatty acids were identified. In Gravyer Cheese samples, the content of volatile fatty acids (Butyric acid and myristic acid ) increase up to 25th day $(\mathrm{P}<0.01)$ and decrease from 45 th day to 90 th day. While levels of free fatty acids (palmitic acid and linoleic acid) generally decrease to 25 th day, they begin increasing again until the end of the maturation period. In the 90 days period of storage of Kars Gravyer Cheese, palmitic, oleic, myristic and stearic acids were found to constitute $74.29 \%$ of the total free fatty acids content. In the samples studied, the most abundant saturated fatty acids were identified as palmitic and stearic acids. Oleic acid was found to be the most abundant unsaturated fatty acid. In cheese samples, the content of monounsaturated fatty acids (MUFA) and polyunsaturated fatty acids (PUFA) ranged $28.38-32.37 \%$ and $1.59-1.84 \%$, respectively. In Kars Gravyer Cheese sample, the Atherogenicity (AI) index was defined as 2.57-3.04.

Conclusion. Fatty acids are precursors of aroma compounds like short and medium chain free fatty acids, ethyl ketones, esters and thioesters, formed in cheese in a result of various biochemical processes. The detection of large amounts of fatty acids with short and medium chains in Gravyer Cheese samples providing aroma, indicate that this cheese is flavorful cheese. 


\section{Introduction}

Today there are about 4000 different varieties of cheese in the world with different aroma and textural properties [1]. The most important factors affecting cheese quality are flavor and aroma of cheese, texture, and appearance. Unique characteristic properties of cheese are formed by biochemical reactions such as glycolysis, proteolysis, and lipolysis occurring during maturation. Free fatty acid (FFA), which emerges as a result of lipolysis reaction, is effective on the flavor and aroma of cheese. FFA is an important, volatile precursor of catabolic reactions, producing compounds that contribute to aroma [2]. The presence of short, medium and long-chain fatty acids is considered the most important indicator of cheese maturation after the compounds formed by glycolytic and proteolytic reactions [3].

The amount of free fatty acids in dairy products has potential effects not only on the taste and texture of dairy products but also on nutrition and health as antimicrobial agents. Determination of fatty acid profile of cheese is also important in terms of these negativities [4]. Cheese, which is an important source of fat in human nutrition, contains a high level of various fatty acids. From a nutritional point of view, different types of cheese contain a high level of digestible fat. Its digestibility is in the range of 88-94\% [5]. However, cheese is usually presented with a negative nutritional image due to the relationship between saturated fatty acids (SFA), the main fatty acids of cheese, and cholesterol, leading to cardiovascular diseases. Although many researchers view SFA as one of the contributing factors in heart disease, there has been no direct link between cardiovascular disease and milk fat, or a real study indicating dairy products' role in heart disease [6]. Cheese is a rich source of some trans-fatty acids and short-chain fatty acids that can be considered as part of a healthy diet [7]. The World Health Organization and the American Heart association have advised that consumers limit their intake of saturated fatty acids and cholesterol to prevent coronary heart disease. The reduction of cholesterol level in dairy products will be an attractive alternative to satisfy consumer's concerns and demands [8]. Gravyer cheese is one of the few European-style cheese that has economic value and is appreciated by consumers like domestic cheese varieties in Turkey [9]. Gravyer Cheese, one of the 18 varieties of cheese that is economically important in the world, is in the same group as Emmental (Switzerland), Gruyere (France), Fontina (Italy), Samso (Denmark), Gouda and Edam (Netherlands) [10]. Approximately 90\% (544 tons) of the production of Gravyer, which is mostly produced in the Eastern Anatolia Region especially in Kars Province and its surroundings, is carried out in Kars [11]. The industrial production of Kars Grayver Cheese is quite low. Production is mostly carried out by traditional methods in dairy farms [12]. Gravyer Cheese is produced in and around Kars Province and takes the first place after kashar, tulum and white cheese production. It has economic value for the people of the region and Kars Gravyer Cheese has brand awareness throughout the country [9].

Although there are many studies on the fatty acid composition and cholesterol content of various cheeses, no studies have been conducted on the determination of changes in cholesterol and fatty acid content during the production and maturation of Kars Gravyer Cheese. However, there are few studies in which the chemical and microbiological properties of Kars Gravyer Cheese, bought from a point of purchase, are revealed [9,13]. Therefore, the aim of this study is to determine the fatty acid composition and cholesterol level of Kars Gravyer Cheese, which will be produced by traditional methods in dairy conditions, and to determine the effect of different maturation periods on fatty acid composition and cholesterol level. 


\section{Materials and methods}

\section{Sample preparation}

Gravyer cheese was produced in a dairy farm in central Boğatepe village of Kars Province according to the flow diagram given in Figure 1. Gravyer cheese production was done in two repetitions. Samples were taken on different maturation days (0th,10th, 25th, 45th, 60th and 90th days) from the produced cheeses and brought to the laboratories under cold chain conditions and fat content, fatty acid composition and cholesterol analyses were performed.

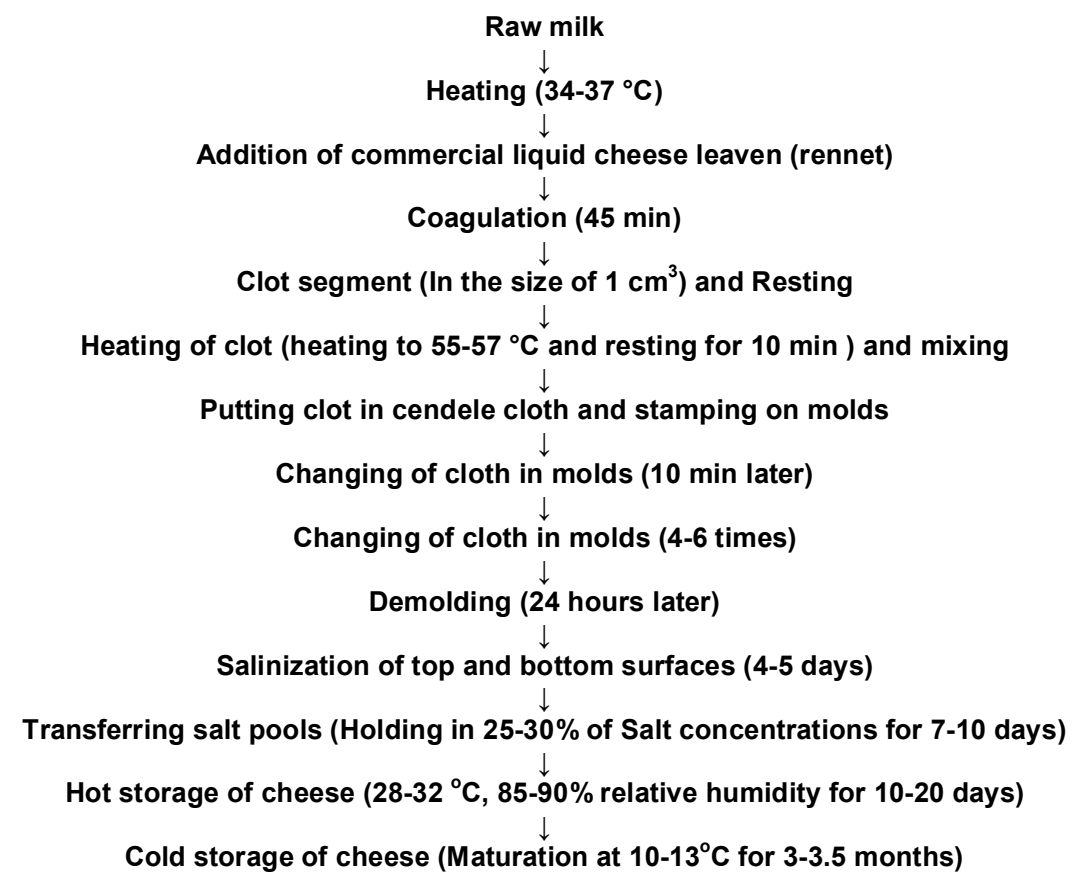

Figure 1. Production flowchart of Gravyer cheese

\section{Methods}

\section{Determination of fat}

The fat content of the samples was determined using Gerber method [14].

\section{Determination of fatty acid composition}

The fatty acid composition of the samples was determined according to the fatty acid methyl ester method (FAME) (AOAC 1996.01) [15]. Approximately $0.1 \mathrm{~g}$ of fat obtained as a result of fat determination method was mixed and shaken with $10 \mathrm{ml}$ of $\mathrm{n}$-hexane and mixed again with a $0.5 \mathrm{ml} 2 \mathrm{~N}$ potassium hydroxide solution with methanol. After standing for 1-2 hours in the dark, $1 \mu \mathrm{l}$ of the supernatant was taken and directly injected into the gas chromatograph. 


\section{- Food Technology -}

\section{GC Conditions for the analysis of fatty Acid composition}

For the fats, the FAME composition was analyzed using a Restek RTX-2330 capillary column (60 m, $0.25 \mathrm{~mm}$ id, $0.1 \mu \mathrm{m}$ film thickness, Bellefonte, PA, USA) in Shimadzu brand gas chromatography (model QP2010 Plus) and a flame ionization detector. The device was given $1 \mu \mathrm{l}$ as the injection volume from the sample. The column furnace temperature was programmed to reach $240{ }^{\circ} \mathrm{C}$ with an increase of $4{ }^{\circ} \mathrm{C} / \mathrm{min}$ after kept for 3 minutes at $100{ }^{\circ} \mathrm{C}$ and to wait 18 minutes at the last temperature value. The injection temperature was set at $250{ }^{\circ} \mathrm{C}$ and the detector temperature was set at $255^{\circ} \mathrm{C}$. Helium was used as a carrier gas. Injection split ratio was used at 1:80 ratio. For the control of the GC/FID system, the LabSolution computer program and FAME Mix standard (37 components) (Restek) were used. FAME peaks were identified by comparing the chain lengths and retention times of the fatty acids specified in the FAME standard.

\section{Determination of cholesterol level}

Cholesterol analysis of samples was done according to [16] with some modifications. According to the method, $1 \mathrm{ml}$ of internal standard (stigmasterol, $0.5 \mathrm{mg} / \mathrm{ml}$ ) and $0.5 \mathrm{ml}$ of $2 \mathrm{~N}$ alcoholic potassium hydroxide solution were added to $0.5 \mathrm{~g}$ of fat and the mixture is left to stand in a water bath at $80{ }^{\circ} \mathrm{C}$ for 15 minutes. Then, after cooling to room temperature, $1 \mathrm{ml}$ of distilled water and $5 \mathrm{ml}$ of $\mathrm{n}$-hexane were added to it and shaken for 1 min. it was then centrifuged at $2000 \mathrm{~g}$ for $1 \mathrm{~min}$ and $1 \mathrm{~mL}$ of the supernatant was removed and injected directly into the gas chromatography device.

\section{GC Conditions for cholesterol analysis}

Cholesterol analysis of samples was performed on a Shimadzu brand gas chromatography (model QP2010 plus) device using Restek Rtx-65TG (30 m x 0.32 mm ID, film thickness $0.1 \mu \mathrm{m}$ ) (Restek international, Bellefonte, PA, USA) silica column (65\% diphenyl-35\% dimethyl-polysiloxane) and flame ionization detector (FID). The column oven temperature was raised to $150{ }^{\circ} \mathrm{C}$ with an increase of $30{ }^{\circ} \mathrm{C} / \mathrm{min}$ and then to $360{ }^{\circ} \mathrm{C}$ with an increase of $15{ }^{\circ} \mathrm{C} / \mathrm{min}$ and kept at this temperature for 3 minutes. Injection port temperature was set at $300{ }^{\circ} \mathrm{C}$ and detector temperature was set at $370{ }^{\circ} \mathrm{C}$, helium was used as the carrier gas. The injection split ratio was used at 1:25.

\section{Lipid quality index}

Unsaturated/saturated fatty acids (USFA / SFA) ratios and desired fatty acids (DFA) were calculated from the fatty acid profiles of the cheeses.

In addition, in order to correlate the fatty acids profile with the risk of cardiovascular disease, the atherogenicity indices (AI) were calculated according to the following equation suggested by the equation by [17].

AI, shows the relationship between the sum of the main saturated FAs and the main classes of unsaturated FAs. The former is considered as proatherogenic (favouring the adhesion of lipids to cells of the immunological and circulatory system), and the latter as anti-atherogenic (inhibiting the aggregation of plaque and diminishing the levels of esterified fatty acid, cholesterol, and phospholipids, thereby preventing the appearance of micro-and macrocoronary diseases) [18]. 


\section{Statistical analysis}

In the evaluation of the obtained results, mean values and standard errors of the samples were determined using SPSS package program, and differences in the fatty acid composition and cholesterol level between fresh and mature Gravyer Cheese samples were analyzed by t-test.

\section{Results and discussions}

Fat ratios of Kars Gravyer Cheese samples are given in Table 1 and cholesterol ratios in Table 2.

Table 1

Fat proportion of Kars Gravyer Cheese during ripening $\left(\bar{X}_{ \pm} S_{x}\right)$

\begin{tabular}{|c|c|c|c|c|c|c|c|c|}
\hline \multirow{2}{*}{ Parameter (\%) } & \multicolumn{8}{|c|}{ Ripening Period (Day) } \\
\cline { 2 - 9 } & 0 & 10 & 25 & 45 & $\mathbf{6 0}$ & 90 & F value & $\mathrm{P}$ \\
\hline \multirow{2}{*}{ Fat } & 27.0 & 28.0 & 29.5 & 33 & 35.57 & 38.5 & 789.97 & $* * *$ \\
& $\pm 0.00 \mathrm{a}$ & $\pm 0.51 \mathrm{~b}$ & $\pm 0.70 \mathrm{c}$ & $\pm 0.71 \mathrm{~d}$ & $\pm 0.72 \mathrm{e}$ & $\pm 0.71 \mathrm{f}$ & & \\
\hline
\end{tabular}

Results are expressed as mean \pm standard deviation of means

$* * *$ a,b,c,d,e,f, $:$ Different letters in the same line refers significant differences between the averages $(P<$ $0.001)$

Cholesterol level of Kars Gravyer Cheese during ripening ( $\mathrm{mg} / \mathbf{1 0 0 g})$

Table 2

\begin{tabular}{|c|c|c|c|c|c|}
\hline \multicolumn{7}{|c|}{ Ripening period (Day) } \\
\hline $\mathbf{0}$ & $\mathbf{1 0}$ & $\mathbf{2 5}$ & $\mathbf{4 5}$ & $\mathbf{6 0}$ & $\mathbf{9 0}$ \\
\hline 45.70 & 48.54 & 58.36 & 155.80 & 104.72 & 101.52 \\
\pm 3.18 & \pm 6.32 & \pm 9.27 & \pm 6.32 & \pm 16.51 & \pm 0.89 \\
\hline
\end{tabular}

Depending on the type of cheese, ripening time varies from a few weeks to three years. The cholesterol ratio of cheese samples ranged from 45.70 to $155.80 \mathrm{mg} / 100 \mathrm{~g}$ during 90 days of maturation. Health lipid indices and the ratio double-carbon saturated of and unsaturated fatty acids in Kars Gravyer Cheese samples is given in Table 3-5.

Table 3

Health lipid indices of Kars Gravyer cheese (mg /100 g)

\begin{tabular}{|c|c|c|c|c|c|c|c|}
\hline & \multicolumn{6}{|c|}{ Kars Gravyer cheese* } & \\
\hline Fatty Acids & $\mathbf{0}$ & 10 & 25 & 45 & 60 & 90 & Total \\
\hline Satured fatty acid & 98.22 & 98.45 & 98.56 & 98.44 & 98.36 & 98.49 & 410.93 \\
\hline SCSFA C4:0-C8:0 & 5.35 & 6.12 & 6.15 & 5.90 & 5.63 & 4.84 & 33.99 \\
\hline MCFA C10:0-C14:0 & 17.34 & 19.47 & 19.24 & 18.48 & 17.59 & 15.95 & 108.07 \\
\hline LCSFAC 16:0-C18:2 & 75.53 & 72.86 & 73.17 & 74.06 & 75.14 & 77.70 & 448.46 \\
\hline MUFA & 30.15 & 28.38 & 28.59 & 29.97 & 32.37 & 31.30 & 180.76 \\
\hline PUFA & 1.84 & 1.84 & 1.84 & 1.76 & 1.80 & 1.59 & 10.64 \\
\hline DFA & 45.52 & 43.46 & 44.16 & 45.31 & 47.98 & 48.05 & 274.48 \\
\hline $\mathrm{AI}$ & 2.79 & 3.04 & 3.01 & 2.83 & 2.57 & 2.71 & 16.95 \\
\hline USFA/SFA & 0.47 & 0.43 & 0.44 & 0.46 & 0.49 & 0.46 & 2.75 \\
\hline
\end{tabular}

*Data were presented as average values; AI - atherogenicity index; 


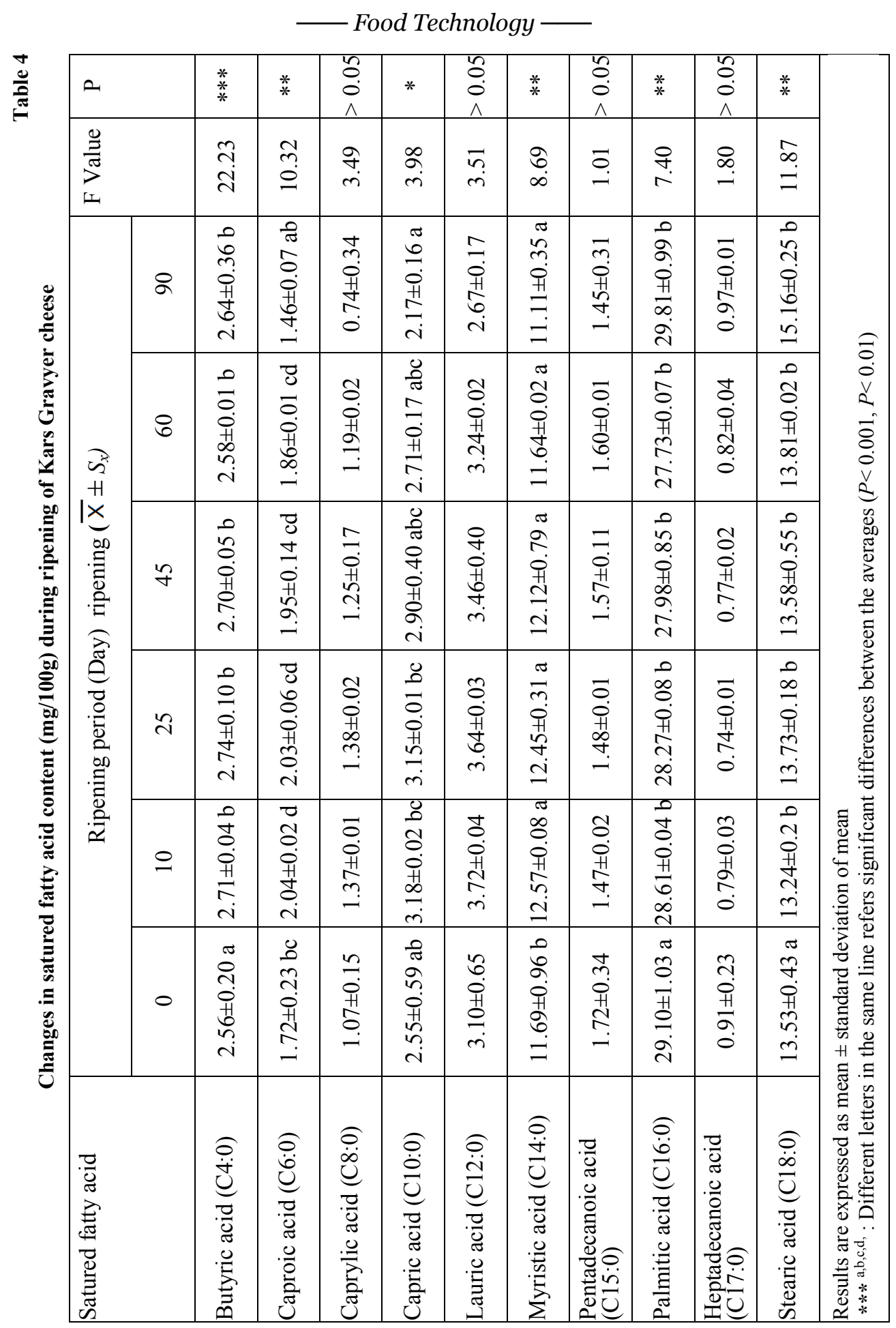


— Food Technology —

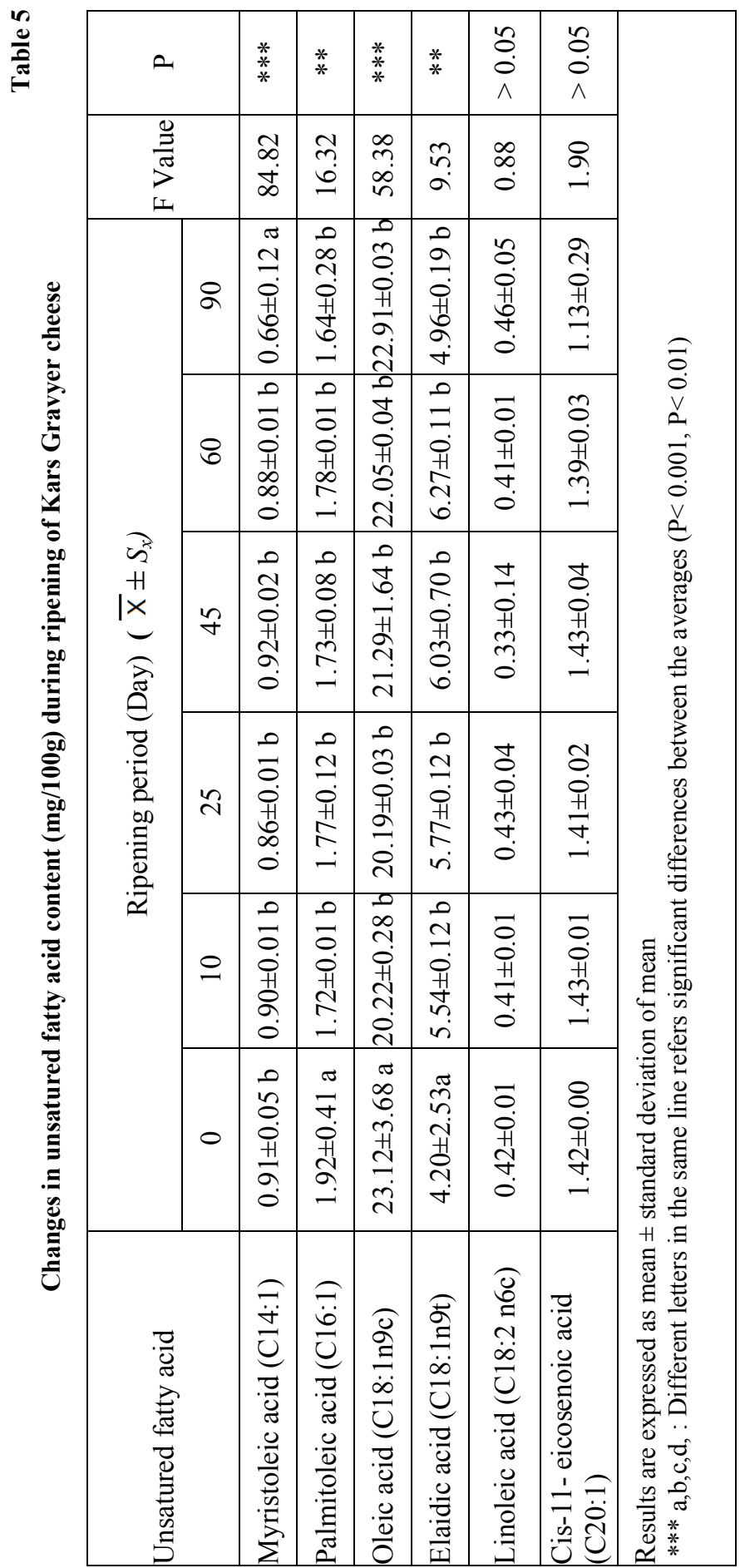


Cheese ripening is a slow and complex biochemical process that is costly due to the long storage period. The formation of biochemical and physical reactions during ripening plays an important role in the texture and taste of matured cheese [19]. The cholesterol ratio of cheese samples increased until the 45th day, decreased by 60th and 90th day. The average amount of cholesterol in cheese samples was found as $85.77 \mathrm{mg} / 100 \mathrm{~g}$. The value found is higher than the value found in Kars Gravyer Cheese $(54.23 \mathrm{mg} / 100)$ by Karagözlü et al. [20] between the values (44.6-147.769 mg/100) found in some local Turkish by Dönmez et al. [21] and close to values $(82.52 \mathrm{mg} / 100 \mathrm{~g})$ in Gouda cheese by Ho-Jung et al. [8].

As a result of the literature review, no research was found related to the determination of fatty acids profile in the production and storage stages of Kars Gravyer Cheese. For this reason, the results obtained from this research will be interpreted taking into consideration the studies conducted in other cheese varieties. Table 4 and 5 show that the fatty acid ratios of the Kars Gravyer Cheese samples changed during the maturation period from the production stage. This may be due to biochemical processes occurring in different maturity periods of the cheeses. Double carbon saturated and unsaturated 16 fatty acids were identified in Kars Gravyer Cheese samples. According to the results of the analysis, the highest fatty acids in the cheese samples were palmitic, oleic, stearic and myristic fatty acids. Ratios of butyric (C4: 0), caproic (C6:0), caprylic (C8:0), capric (C10:0), lauric (C12:0), myristic (C14:0), pentadekanoic (C15:0), palmitic (C16:0), heptadecanoic (C17:0), stearic (C18:0), myristoleic acid (C14:1), palmitoleic (C16:1), oleic (C18:1), elaidic (C18:1 (trans 9), linoleic (C18: 2) and 11 -eicosenoic (C20: 1) acid identified in cheese samples ranged between $2.56-2.74 \mathrm{mg} / 100 \mathrm{~g}, 1.46-2.04 \mathrm{mg} / 100 \mathrm{~g}, 0.74-1.38 \mathrm{mg} / 100 \mathrm{~g}, 2.17-3.18$ $\mathrm{mg} / 100 \mathrm{~g}, 2.67-3.72 \mathrm{mg} / 100 \mathrm{~g}, 11.11-12.57 \mathrm{mg} / 100 \mathrm{~g}, 1.45-1.72 \mathrm{mg} / 100 \mathrm{~g}, 27.73-29.81$ $\mathrm{mg} / 100 \mathrm{~g}, \quad 0.74-0.97 \mathrm{mg} / 100 \mathrm{~g}, \quad 13.24-15.16 \mathrm{mg} / 100 \mathrm{~g}, \quad 0.66-0.92 \mathrm{mg} / 100 \mathrm{~g}, \quad 1.64$ $1.92 \mathrm{mg} / 100 \mathrm{~g}, 20.19-23.12 \mathrm{mg} 100 \mathrm{~g}, 4.20-6.27 \mathrm{mg} / 100 \mathrm{~g}, 0.33-0.46 \mathrm{mg} / 100 \mathrm{~g}$ and $1.13-$ $1.43 \mathrm{mg} / 100 \mathrm{~g}$ respectively.

Changes in the total free fatty acids C4, C6, C10, C14, C16, C18, C14:1, C16:1, $\mathrm{C} 18: 1 \mathrm{~N} 9 \mathrm{~T}$ and $\mathrm{C} 18: 1 \mathrm{n} 9 \mathrm{C}$ values of all cheese samples during the ripening period were statistically significant $(P<0.001, P<0.01, P<0.05)$ and the changes in $\mathrm{C} 8, \mathrm{C} 12, \mathrm{C} 17$, $\mathrm{C} 18: 2$ and $\mathrm{C} 20: \ln 9$ values were statistically insignificant $(P>0.05)$.

Abd El-Salam [22] reported that milk varieties, maturation temperature, salt concentration, milk lipase, starter bacteria and other microbial lipases were also effective on the formation of free fatty acids in cheese such as Feta and Teleme. Free fatty acids are primarily formed by the enzymatic breakdown of glycerides in dairy products [23]. Free fatty acids, as they directly contribute to the flavor of the cheese, also play a role in many types of reactions leading to the formation of methyl ketones, secondary alcohols, aliphatic and aromatic esters [24]. The free volatile fatty acids found in cheeses are closely related to flavor and aroma, and acetic, butyric, caproic, caprylic and capric acids are the most important free fatty acids affecting the cheese flavor [24].

In Kars Gravyer Cheese samples, the amount of volatile fatty acids (C4: 0-C14: 0 ) increased up to 25 th day $(P<0.01)$ and decreased from 45 th day to 90 th day. While levels of free fatty acids (C16: 0-C18: 2) generally decrease at day 25, they have begun to increase again until the end of the ripening period. Kara et al. [25] stated that the proportion of fatty acids in tulum cheese increased until the 30th day and then decreased until the 90th day. In the studies carried out by different researchers [26-28]. the level of volatile fatty acids has been reported to rise during maturation. Unlike other studies, free fatty acids increased up to the 25th day and then decreased periodically (45-90 days). The reason for the decline in free fatty acids between 45 and 90 days is that some of the free fatty acids that occur at the 
end of maturation are converted into $\beta$-oxidation and methyl ketones, carbonyl compounds and other decomposition products [29].

Short and mid-chain saturated free fatty acids such as butyric, caproic, caprylic and capric acid are often the result of lipolysis of triglycerides by molds. However, in some cases, fatty acids containing up to six carbon atoms can be formed by the reduction of lactose and amino acids or the oxidation of ketones, aldehydes, and esters ([30]. Short and medium chain fatty acids have a low sensory perception threshold and have a more significant effect on the flavor development of cheese than long chain fatty acids.

In this study, the average values of butyric, caproic, caprylic and capricic acid during 90 days maturation period in Kars Gravyer cheese were found as $2.56-2.74 \mathrm{mg} / 100 \mathrm{~g}, 1.72-$ $2.04 \mathrm{mg} / 100 \mathrm{~g}, 1.07-1.38 \mathrm{mg} / 100 \mathrm{~g}$ and $2.55-3.18 \mathrm{mg} / 100 \mathrm{~g}$ respectively. The values obtained are higher than the values found by Türkoğlu, [27], in braided cheese and by Atasoy et al. [26], in Urfa cheese and lower than the values found in Van Otlu Cheese by Ocak et al. [31], and the values found in 11 different cheese varieties by Hayaloğlu et al. [32], Palmitic, oleic, myristic and stearic acid formed in gravyer cheese during maturation accounted for $74.29 \%$ of the total free fatty acids content. The most abundant fatty acids in fresh and ripe gravyer cheeses are palmitic acid (C16:0). This ratio varied between 27.73$29.81 \mathrm{mg} / 100 \mathrm{~g}$. Other acids following this fatty acid are oleic (C18:1) (20.19-23.12 $\mathrm{mg} / 100 \mathrm{~g})$ stearic acid (C18:0) (13.24-15.16) and myristic acid (C14:0) (11.11-12.57) respectively. This may be due to the presence of large amounts of palmitic, oleic, stearic and myristic fatty acids in milk fat [33]. The values identified in gravyer cheese are higher than the values obtained by Atasoy et al. [26], in Urfa cheese (myristic acid 6.37-12.40 $\mathrm{mg} / 100 \mathrm{~g}$, palmitic acid $18.0-26.9 \mathrm{mg} / 100 \mathrm{~g}$ and oleic acid $12.7-19.00 \mathrm{mg} / 100 \mathrm{~g}$ ) and lower than the values found in 11 different cheese varieties (myristic acid $6.2-139.7 \mathrm{mg} / 100 \mathrm{~g}$, palmitic acid $19.9-356.7 \mathrm{mg} / 100 \mathrm{~g}$ and $17.6-386.3 \mathrm{mg} / 100 \mathrm{~g}$ ) by Hayaloğlu et al. [32], Mallatou et al. [34], reported that although palmitic, stearic and oleic fatty acids form dominant fatty acids in feta cheese, these fatty acids were not as effective as short-chain fatty acids on cheese flavor. Lauric acid (C12:0) is the predominant fatty acid (2.67-3.72 $\mathrm{mg} / 100 \mathrm{~g}$ ) among short and medium-chain fatty acids. Aminifar et al. [35], Marrone et al. [36], and Ocak, et al. [31]. Şengül et al. [3], and Arslaner et al. [28], reported that palmitic, myristic, stearic and oleic fatty acids had the highest proportion among the fatty acids in Lighvan cheese, in Pecorino Carmastiano cheese, in fresh and ripe Herbed cheeses, in Karın kaymağ 1 cheese samples and in Tulum cheese respectively. In addition, Ocak et al. [31], stated that lauric acid (C12:0) was the predominant fatty acid among short and medium-chain fatty acids. The amounts of oleic and especially linoleic acid, which are very important in terms of nutrition physiology and which cause certain dermatological diseases and increase in the water permeability of cells in their deficiency or absence in the diet are determined as $20.19-23.12 \mathrm{mg} / 100 \mathrm{~g}$ and $0.33-0.46 \mathrm{mg} / 100 \mathrm{~g}$ respectively.

Elaidic acid (C18:1) acid level increased up to 60 days during maturation but decreased for 90 days. The contents of linoleic acid (C18: 2) $(0.33-0.46 \mathrm{mg} / 100 \mathrm{~g})$ and cis-11eicosenoic acid (C20:1) (1.13-1.43 mg/100g) of fresh and ripe Gravyer cheeses were found to vary within a narrow range. Cheese fat contains saturated (SFA), monounsaturated (MUFA) and polyunsaturated (PUFA) fatty acids. Milk fat generally contains approximately $66 \%$ saturated (SFA) $(57.4 \%$ palmitic, $21.6 \%$ myristic and $17.6 \%$ stearic), $30 \%$ monounsaturated (MUFA) and $4 \%$ polyunsaturated fatty acids (PUFA) (LópezExpósito, Amigo, \& Recio, 2012). Of the fatty acids identified in the cheese samples, $68.22 \%$ were saturated fatty acids and $31.77 \%$ were unsaturated fatty acids. Dönmezet al. [21], determined saturated fatty acid ratio as $60.80-76.57 \%$. Short, medium and long chain fatty acids were determined as $4.84-6.15 \%, 15.95-19.47 \%$ and $71.43-76.57 \%$ in Kars 
Gravyer Cheese samples, respectively. According to values determined in Gravyer Cheese: Atasoy et al. [26], in Urfa cheese $(7-8 \%, 20-23 \%$ and $70-72 \%)$ and Sert et al. [38], found in tulum cheese $(15.08-22.51 \%, 39.13-42.62 \%$ and $30.92-38.56 \%)$, Turkoglu [27], found in braided cheese (medium and long chain fatty acids $24-27 \%$ and $63-72 \%$ ) that short chain (SCSFA) and medium-chain (MCSFA) fatty acids were low and low-chain fatty acids (LCSFA) were high in concentration. In cheese samples, the proportions of monounsaturated fatty acid (MUFA) and polyunsaturated fatty acid (PUFA) were found to be $28.38-32.37 \%$ and $1.59-1.84 \%$, respectively Dönmez et al. [21], found in some traditional Turkish cheeses, that MUFA was $21.42-34.05 \%$ and PUFA $1.47-3.59 \%$ and Kinık et al. [39]. In 29 different hard and soft cheese varieties, MUFA was determined as 24.14-27.63 and PUFA as $0.72-1.58 \%$. The values found in Gravyer cheese were higher than found by Kınık, et al. [39], approximately around the same MUFA value range found by Dönmez et al. [21], and lower than the PUFA values of the same study.

The Atherogenicity (AI) index, desired fatty acids (DFA) and ASFA / SFA ratios were determined as 2.57-3.04, 43.46-48.05 and 0.43-0.49 in Kars Gravyer Cheese samples, respectively. The values found were higher than the AI value determined in traditional Serbian white cheese (1.89-3.06) by Barac et al. [5], in Serbian traditional white cheeses, higher than the lower limit of DFA (34.45-46.34), lower than the upper limit, and higher than USFA/SFA $(0.30-0.51)$.

\section{Conclusion}

This study was the first to examine the changes in free fatty acids and cholesterol levels and examine the effect of ripening days on the change of fatty acid composition and cholesterol level during maturation starting from production. In the 90 day storage period of Kars Gravyer Cheese, palmitic, oleic, myristic and stearic acid constituted $74.29 \%$ of the total free fatty acids content and while the most abundant saturated fatty acids were palmitic and stearic acid, oleic acid was the most abundant unsaturated fatty acid. The cholesterol content of cheese samples ranged from 45.70 to $55.80 \mathrm{mg} / 100 \mathrm{~g}$ during 90 days of maturation. In this study, the distribution of saturated and unsaturated fatty acids in milk fat, which is very important in terms of human nutrition, was determined in Kars Gravyer Cheese. In cheese samples, 10 saturated fatty acids and 6 unsaturated fatty acids were determined and medium and long-chain fatty acid ratios were found to be higher than short chain fatty acids. Conversion of triglycerides into free fatty acids by microorganisms and natural milk lipase plays an important role in the development of different aroma substances in ripe cheeses. Especially short and medium chain free fatty acids are used as precursors in the formation of aromatic products such as ethyl ketones, esters and thioesters $[31,40]$. It can be said that Kars Gravyer Cheese is a very aromatic cheese because it contains short and medium chain fatty acids which have an important effect on the flavor and aroma of milk and dairy products. Having said that, this research is also important in terms of shedding light on the research to be carried out in the future.

Acknowledgements

Authors wish to thank the Research Fund of Kafkas University (No. 2017-FM-02) for the financial support. 


\section{References}

1. Üçüncü M. (2004), A’dan Z’ye Peynir Teknolojisi, Ege Üniversitesi Mühendislik Fakültesi, Gıda Müh. Bölümü. Cilt 1. Bornova/ İzmir.

2. McSweeney P.L.H., Sousa M.J. (2000), Biochemical pathways for the production of flavour compounds in cheeses during ripening. A review, Lait, 80, pp. 293-324.

3. Şengül M., Erkaya E., Ceyhun A.E.(2011), Fatty acid composition of Karın Kaymağı cheese, Journal of the Faculty of Agriculture, 42(1), pp. 57-62.

4. Kilcawley K.N., Mannion D.T. (2017), Free Fatty Acids Quantification In Dairy Products, World's largest Science, Technology \& Medicine Open Access book Publisher, pp. 209-220.

5. Barać M., Kresojević M., Špirović-Trifunović B., Pešić M., Vučić T., Kostić A. Despotović S. (2018), Fatty acid profiles and mineral content of Serbian traditional white brined cheeses, Mljekarstvo, 68(1), pp. 37-45

6. Kanekanian A. (2014), The health benefits of bioactive compounds from milk and dairy products, In: Milk and Dairy Products as Functional Foods, ed A. Kanekanian, John Wiley \& Sons, Ltd, Oxford, pp. 1-22.

7. Lock A.L., Givens D.I., Bauman D.E., (2014), Dairy fat: Perceptions and realities. In: Milk and Dairy Products as Functional Foods, Ed. A. Kanekanian, John Wiley \& Sons, Ltd, Oxford, pp. 174-192.

8. Ho-Jung J., Eun-Jung K., Hae-Soo K.(2013), Comparison of physicochemical and sensory properties between cholesterol-removed Gouda cheese and Gouda cheese during ripening, Asian Australasian Association of Animal Science, 26(12), pp. 1773-1780.

9. Ulutaş Z., Çağlar A., Kurt A. (1993), Kars Gravyer peynirinin yapıllışı, duyusal fiziksel ve kimyasal özellikleri üzerinde bir araştırma, Glda, 18 (3), pp. 197-202. (In Turkish).

10. Adam R.C. (1956), Türkiye Süt ve Mamullerinin Bileşimi, Ankara Üniversitesi, 92, Ankara.

11. Anon (2015), Kars 2015 yll süt ve ürünleri kapasite raporu. Kars Sanayi ve Ticaret Odası Müdürlü̈̆̈̈, Kars/Turkiye (In Turkish)

12. Anon (2007), Düzey II bölgeleri kalkınma programı, pazarlama araştırmalarl, süt ve süt ürünleri- TRA2, RD-AKKM.419.TR.

13. Topuk Ş., Sezer Ç. (2015), Some quality characterıstıcs of Kars Gravyer cheese, The Journal of Food, 40(2), pp. 69-75.

14. Turkish Standards (1978), (Van Gulik Methods) Official methods of analysis, Turkish Standards Institution, Ankara.

15. Satchithanandam S., Fritsche J., Rader J.I. (2001), Extension of AOAC Official Method 996.01 to the Analysis of Standard Reference Material (SRM) 1846 and Infant Formula, Journal of AOAC Int,. 84, pp. 805.

16. Fletouris D.J., Botsoglou N.A., Psomas I.E., Mant1s A.I. (1998), Rapid determination of cholesterol İn milk and milk products By direct saponification and capillary gas chromatography, Journal of Dairy Science, 81(11), pp. 2833-2840.

17. Ulbricht T.L.V., Southgate D.A.T. (1991), Coronary heart disease: seven dietary factors. The Lancet, 338(8773), pp. 985-992.

18. Prandini A., S. Sigolo, G. Piva A. (2011), Comparative study of fatty acid composition and CLA concentration in commercial cheeses, Journal of Food Composition and Analysis, 24(1), pp. 5561.

19. Tunick M. H. (2000), Rheology of dairy foods that gel, stretch and fracture, Journal of Dairy Science, 83(8), pp. 1892-1898.

20. Karagözlü C., Yerlikaya O., Akpınar A., Ünal G., Ergönül B., Ender G., H.R. Uysal H.R. (2016), Cholesterol levels and some nutritional parametres of traditional cheeses in Turkey, Ege Üniversitesi Ziraat Fakültesi Dergisi, 53(2), pp. 161-168.

21. Dönmez M., Seçkin A.K., Sağdıç O., Şimşek B. (2005), Chemical chracteristics fatty acid compositions conjugated linoleic acid contents and cholesterol levels of some tradional Turkish cheeses, International Journal of Food Sciences and Nutrition, 56 (3), pp. 157-163.

22. Abd El-Salam M.H. (1987), Domiati and Feta Type Cheeses. Cheese: Chemistry, Physics and Microbiology, Elsevier Applied Science, London. pp. 277-309. 
23. Deeth H.C. Fitz-Gerald C.H. (1995), Lipolyticenzymes and Hydrolytic Rancidity In Milk and Milk Products, In P. F. Fox (Ed.), Advanced dairy chemistry-2.Lipids, Chapman \& Hal, London.

24. Karaca O.B. (2007), Effects of using proteolytic and lipolytic enzyme from microbiolojical sources on ripening and properties of white cheese, Department of Food Engineering Institute of Naturel and Applied Sciences University of Çukurova. PhD thesis, Adana-Turkey.

25. Kara R., Bulut S., Akkaya L. (2014), Determination of fatty acid composition of Afyon Tulum cheese, Journal of Food and Nutrition Research, 28(2), pp. 17-20.

26. Atasoy A.F., Türkoğlu H. (2008), Changes of composition and free fatty acid contents of Urfa cheeses (a white-brined Turkish cheese) during ripening: Effects of heat treatments and starter cultures, Food Chemistry, 110(3), pp. 598-604

27. Türkoğlu T. (2011), Free fatty acid composition and sensory characteristics of Örgü cheese, Scientific Research and Essays, 6(7), pp. 1555-1560.

28. Arslaner A., Bakırc1 I. (2016), Effect of milk type, pasteurization and packaging materials on some physicochemical properties and free fatty acid profiles of tulum cheese, Akademik Grda, 14(29), pp. 98-104.

29. Akyüz A. (2003), Effect of some spices extracts added on lypolysis of White cheese during ripening, The Journal of Food, 28(3), pp. 295-303.

30. Molimard P., Spinnler H.E.(1996), Review: compounds involved in the flavour of surface mondripened cheeses: origins and properties, Journal of Dairy Science, 79, pp. 169-184.

31. Ocak E., Tunçtürk Y., Javıdıpour I, Köse Ş.( 2015), The changes in the Van herby cheeses made from different variety of milks during ripening: microbiological changes, lipolysis and free fatty acids, YYU J AGR SCI, 25(2), pp. 164-173.

32. Hayaloglu A.A., I. Karabulut I.(2013), Characterization and comparison of free fatty acid profiles of eleven varieties of Turkish cheeses, International Journal of Food Properties, 16(6), pp. 1407-1416.

33. Christie W.W. (1983), The Composition and Structure of Milk Lipids, In P. F. Fox (Ed.), Developments in dairy chemistry. Lipids, 2, Applied Science Publishers, London.

34. Mallatou H., Pappa E., Massouras T. (2003), Changes in free fatty acids in during ripening of Teleme cheese made with ewes, goats, cows or a mixture of ewes and goats milk, International Dairy Journal, 13(2/3), pp. 211-219.

35. Aminifar M., Emam-Djomeh Z. (2014), Changes of texture, microstructure and free fatty acid contents of lighvan cheese during accelerated ripening with lipase, J of Agri. Sci. and Techn. 16(6), pp. 113-123.

36. Marrone R., Balestrieri A., Pepe T.,Vollano L., Murru N., D’Occhio M.J, Anastasio A. (2014), Physicochemical composition, fatty acid profile and cholesterol content of "Pecorino Carmasciano" cheese, a traditional Italian dairy product, Journal of Food Composition and Analysis, 36(1-2), pp. 2-20.

37. López-Expósito I., Amigo L., Recio I. (2012), A mini-review on health and nutritional aspects of cheese with a focus on bioactive peptides, Dairy Science and Technology. 92(5), pp. 419-438.

38. Sert D., Akın N., Aktumsek A. (2014), Lipolysis in Tulum cheese produced from raw and pasteurized goats' milk during ripening, Small Ruminant Research, 121, pp. 351-360.

39. Kınık Ö., Gursoy O., Seckin A.K.(2005), Cholesterol content and fatty acid composition of most consumed Turkish hard and soft cheeses, Czech Journal Food Science, 23(4), pp. 166-172 .

40. Collins Y.F., McSweeney P.L.H., Wilkinson M.G. (2003), Lipolysis and free fatty acid catabolism in cheese: a review of current knowledge, International Dairy Journal, 13(11), pp. 841-866. 